\title{
Trend Analyses of Parameters of Equations for Overall Node Energy Savings Achievable in ubicomp MANETs using Location-Aware Transmission.
}

\author{
M. Kaleem GALAMALI, Assoc. Prof Nawaz MOHAMUDALLY
}

\begin{abstract}
Location-Tracking and corresponding applications based on it together with modern functionalities are being developed in the field of ubicomp [31-67]. MANET transmission strategies also remain subject to research. The field of ubicomp, however, suffers from an underdeveloped area of metric development, analysis and modelling for predictability purposes compared to the current level of development in the field of software engineering. Such information in ubicomp will serve towards better gearing of future investments. An area of concern here is energy considerations in ubicomp since devices still suffer from constrained battery availability. A previous research [15] was carried out to assess how much energy savings can be achieved by overall nodes in location-aware MANET transmission and the corresponding trend was put forward as following a normal distribution model.
\end{abstract}

In this paper, the next set of question to be investigated is legitimately put forward as: "What are the trends of variation observable within each parameter of the equation of normal curve obtained for metric OES [15] over varying node densities?"

The need for studying the behaviour of components of an applicable model for OES and successively model the behaviour of each component mathematically is felt required since it involves a lot of work. Results obtained may be used by designers to better predict ubicomp behaviour and formulate correspondingly better architectures. This paper is a follow-up of previous papers [1-30].

Key terms: Ubicomp- Ubiquitous Computing, MAUCMobile and Ubiquitous Computing, ES- Energy Savings, OES- Overall ES, MANET- Mobile Adhoc Network, CBR- Constant Bit Rate.

M. Kaleem GALAMALI,

University of Technology Mauritius (student) Mauritius

Assoc. Prof Nawaz Mohamudally University of Technology Mauritius, Mauritius

\section{Introduction}

Many factors affect energy consumption in MAUC [2]. Still another factor is type of transmission whereby MANET transmission and successively node density become very significant. In a previous research [15], an attempt has been made through simulation experiments, to find a particular trend/model which depicts energy savings that can be reached by overall nodes in MAUC (OES) to rate the effectiveness of location-aware MANET transmission strategies compared to the theoretical/empirical models derived in simulations. The model put forward for metric OES was the normal distribution model of form:

$F(x)=b *(1 /(a * \operatorname{sqrt}(2 * p i))) * \exp \left(-(x-c)^{2} / 2 * a * a\right)$

Here also, the equation of the model comprises of three parameters: $a, b$ and $c$. the next level of research is to study the mathematical modelling of the parameters of the equation obtained above and successively deriving the model of variation for each parameter.

The key contributions of this paper is the establishment of the trend of variation for each parameter of the equation of the normal distribution model for metric OES presented in previous paper [15] by using the same tabular data presented in that same paper, covering node numbers 7 until 56. Availability of such mathematical methods will certainly help designers to better understand the evolution and predictability of ubicomp behaviour in a manner that these methods may easily be implemented into a software program for future adaptability requirements of ubicomp following different situations observed. The rest of this paper is organised as follows: section 2- Parameter Trend Analysis- Metric OES, section 3- Conclusion and References.

\section{Parameter Trend Analysis - Metric OES. \\ 2.0 General Procedure Adopted.}

The tabulated data for each parameter of equation of model for OES is plotted onto gnuplot over Linux. Graphical analyses using smooth bezier support and "fit" command is performed. General observations, for each such graph obtained is reported. Several equations of fit have been tried and a summary is reported for each OES parameter of equation. Ultimately, choice is made taking into consideration firstly the value of least reduced chi-square and secondly most plausible extendability produced at node numbers 80 and 100 . 
Finally, the values of parameters for each OES parameter of equation is also noted.

\subsection{Trend Analysis - OES parameter " $a$ ".}

Generally the curve depicts a decreasing tendency at a decreasing rate until about node number 36 after which the curve increases slowly. A slight oscillation or even damped oscillation is perceived but has been difficult to accommodate in an equation since high ch_sq value was being obtained.

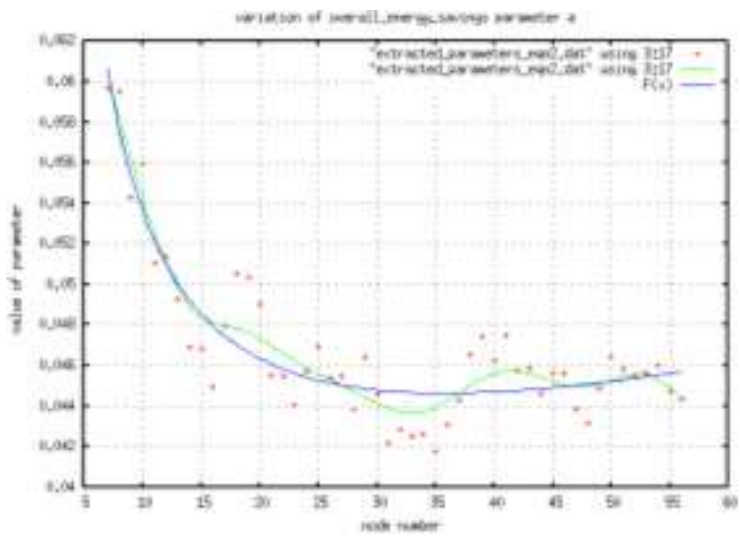

Figure 1: OES parameter a

The equation of best fit is

$$
\begin{aligned}
& \mathrm{F}(\mathrm{x})=\left(\mathrm{a} * \exp \left(\left(\mathrm{b} * \mathrm{x}^{0.5}\right)+\mathrm{c}\right)+\mathrm{d}\right) /\left(\mathrm{x}^{0.5}\right)+\left(\mathrm{f} / \mathrm{x}^{1.5}\right) \\
& \text { Ch_sq }=3.02622\left(\mathrm{e}^{-06}\right) \quad \mathrm{F}(80)=0.048245 \\
& \mathrm{~F}(100)=0.05080358
\end{aligned}
$$

The parameters of fit are:

$\mathrm{a}=0.145884, \mathrm{~b}=0.130511, \mathrm{c}=0.104894, \mathrm{~d}=-0.091$ $0876, \mathrm{f}=0.158455$

\subsection{Trend Analysis - OES parameter " $b$ ”.}

A similar curve for trend as for OES parameter "a" is observable here.

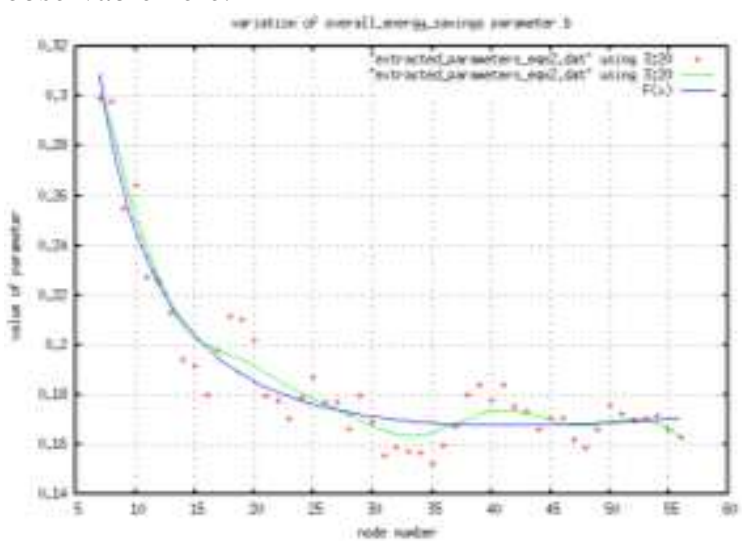

Figure 2: OES parameter b

The equation of best fit is

$$
\begin{gathered}
F(x)=\left(a * \exp \left(\left(b * x^{0.5}\right)+c\right)+d\right) /\left(x^{0.5}\right)+\left(f / x^{1.5}\right) \\
\text { Ch_sq }=0.000114899 \quad F(80)=0.1817417 \\
F(100)=0.194367
\end{gathered}
$$

The parameters of best fit are:

$\mathrm{a}=0.329893, \mathrm{~b}=0.170636, \mathrm{c}=0.0761654, \mathrm{~d}=$ $0.0381963, \mathrm{f}=2.07051$.

\subsection{Trend Analysis - OES parameter " $c$ ".}

The curve obtained depicts a steady decrease at a decreasing rate. Again, a slight oscillation is noticed but it is difficult to work with.

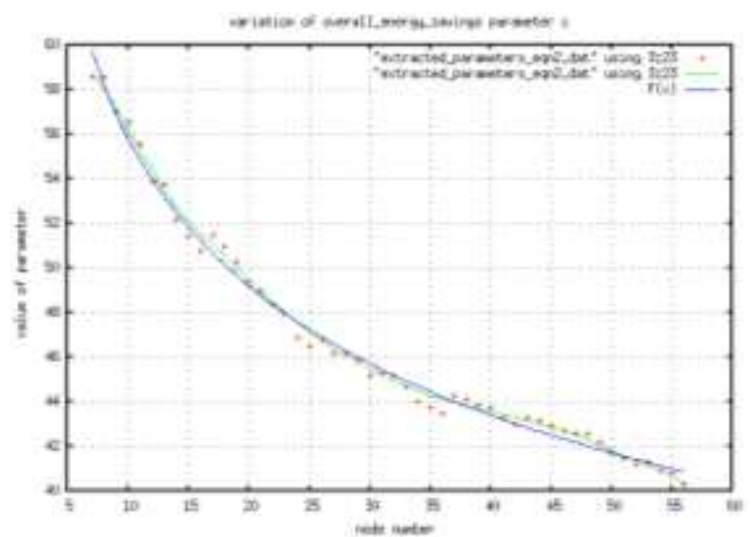

Figure 3: OES parameter c

The potentially applicable equations are:

$$
\begin{aligned}
& \text { 1. } F(x)=d * x+f \\
& \text { Ch_sq }=2.67646 \\
& \text { 2. } F(x)=(a / \log (b * x))+c \\
& \text { Ch_sq }=0.219049 \quad \mathrm{~F}(80)=38.32495 \\
& \mathrm{~F}(100)=36.824916
\end{aligned}
$$

\section{Choice of best fit for OES parameter c}

The equation in part 2 above has been selected because of smallest ch_sq and good extendability over larger node numbers. The parameters obtained for best fit are: $a=840.388, b=802.688, c=-37.5909$

\section{Conclusion.}

This piece of research was aimed at and has developed the models of trends of the parameters of equations for the metric OES in a MANET topography of $300 \times 300$ $\mathrm{m}^{2}$. The models put forward have involved quite complicated mathematical equations and will assist in studying MANETs for MAUC environment from a software engineering perspective. The mathematical models can be mapped onto programming algorithms. The experiment was carried out in NS-2 over linux. The plottings and "fit" attempts were done in gnuplot. Best fit was evaluated from reduced chi-square values and best extendability of equations obtained.

Assumptions stated in previous paper [15] hold here also. Gnuplot is also assumed as appropriate. The intrinsic constructs of gnuplot is not criticised here. 
Further work identified remain: formulating methods of predictability for metric OES and its trend and reporting observations of certain critical values identified.

\section{References}

[1] M. Kaleem GALAMALI, Assoc. Prof Nawaz MOHAMUDALLY, Towards Dependable Pervasive Systems-A Position and Vision Paper, CEET 2014

[2] M. Kaleem GALAMALI, Assoc. Prof Nawaz MOHAMUDALLY, Model of Energy Savings achievable with Location-aware Node-to-Node Transmission in UbiComp , CEET 2014

[3] M. Kaleem GALAMALI, Assoc. Prof Nawaz MOHAMUDALLY, Model of Energy Savings achievable with Location-aware Node-to-Node Transmission in UbiComp Using Location Refresh Intervals, CEET 2014

[4] M. Kaleem GALAMALI, Assoc. Prof Nawaz MOHAMUDALLY, Model of Energy Savings achievable with Location-aware Transmission in UbiComp Using Relays, CEET 2014

[5] M. Kaleem GALAMALI, Assoc. Prof Nawaz MOHAMUDALLY, Mathematical modeling of need of exact number of relays to ensure seamless mobility in mobile computing, CEET 2014

[6] M. Kaleem GALAMALI, Assoc. Prof Nawaz MOHAMUDALLY, Modelling of need for multiple relays for ensuring seamless mobility, CEET 2014

[7] M. Kaleem GALAMALI, Assoc. Prof Nawaz MOHAMUDALLY, Investigation of prominence of placements of relays in a ubicomp topography,

[8] M. Kaleem GALAMALI, Assoc. Prof Nawaz MOHAMUDALLY, Model of energy savings achievable with location-aware transmission in ubicomp using optimised number of relays.

[9] M. Kaleem GALAMALI, Assoc. Prof Nawaz MOHAMUDALLY, Investigation of Prominence of Placements of Optimised Number of Relays in a Ubicomp Topography using Location-Aware Transmission, CEET 2015.

[10] M. Kaleem GALAMALI, Assoc. Prof Nawaz MOHAMUDALLY, Extending Node Battery Availability in Ubicomp with Location-Aware Transmission, CEET 2015.

[11] M. Kaleem GALAMALI, Assoc. Prof Nawaz MOHAMUDALLY, Extending Node Battery Availability in Ubicomp with Location-Aware Transmission using Location Refresh Intervals, CEET 2015.

[12] M. Kaleem GALAMALI, Assoc. Prof Nawaz MOHAMUDALLY, Extending Node Battery Availability in Ubicomp with Location-Aware Transmission using Uniformly Placed Relays, CEET 2015.

[13] M. Kaleem GALAMALI, Assoc. Prof Nawaz MOHAMUDALLY, Extending Node Battery Availability in Ubicomp with Location-Aware Transmission Using Optimally Placed Relays, CEET 2015.

[14] M. Kaleem GALAMALI, Assoc. Prof Nawaz MOHAMUDALLY, Model of Sender Node Energy Savings Achievable with Location-Aware MANET Transmission in Ubicomp. ACCN 2016

[15] M. Kaleem GALAMALI, Assoc. Prof Nawaz MOHAMUDALLY, Model of Overall Node Energy Savings Achievable with Location-Aware MANET Transmission in Ubicomp. ACCN 2016

[16] M. Kaleem GALAMALI, Assoc. Prof Nawaz MOHAMUDALLY, Model of Sender Node Extra Energy Savings Achievable in MANET Against Direct Node-toNode Transmission Using Location-Aware Transmission in Ubicomp. ACCN 2016

[17] M. Kaleem GALAMALI, Assoc. Prof Nawaz MOHAMUDALLY, Model of Overall Node Extra Energy Savings Achievable in MANET against Direct Node-toNode Transmission Using Location-Aware Transmission in
Ubicomp. ACCN 2016

[18] M. Kaleem GALAMALI, Assoc. Prof Nawaz MOHAMUDALLY, Model of Energy Consumption Ratio Achievable in MANET Using Location-Aware Transmission in Ubicomp. ACCN 2016

[19] M. Kaleem GALAMALI, Assoc. Prof Nawaz MOHAMUDALLY, Model of Minimum Energy Consumption Ratio Achievable in MANET Using LocationAware Transmission in Ubicomp. ACCN 2016

[20] M. Kaleem GALAMALI, Assoc. Prof Nawaz MOHAMUDALLY, Model of Maximum Energy Consumption Ratio Achievable in MANET Using LocationAware Transmission in Ubicomp. ACCN 2016

[21] M. Kaleem GALAMALI, Assoc. Prof Nawaz MOHAMUDALLY, Model of Overall Energy Consumption Fairness Ratio Achievable in MANET Using LocationAware Transmission in Ubicomp. ACCN 2016

[22] M. Kaleem GALAMALI, Assoc. Prof Nawaz MOHAMUDALLY, Model of Overall Energy Consumption Fairness Proportion Achievable in MANET Using LocationAware Transmission for Ubicomp, CEET 2016

[23] M. Kaleem GALAMALI, Assoc. Prof Nawaz MOHAMUDALLY, Model of Minimum Fairness Proportion Achievable in MANET Using Location-Aware Transmission for Ubicomp, CEET 2016

[24] M. Kaleem GALAMALI, Assoc. Prof Nawaz MOHAMUDALLY, Model of Maximum Fairness Proportion Achievable in MANET Using Location-Aware Transmission for Ubicomp, CEET 2016

[25] M. Kaleem GALAMALI, Assoc. Prof Nawaz MOHAMUDALLY, Model of Sender Fairness Proportion Achievable in MANET Using Location-Aware Transmission for Ubicomp, CEET 2016

[26] M. Kaleem GALAMALI, Assoc. Prof Nawaz MOHAMUDALLY, Model of Distance Travelled by packets in MANETs using Location-Aware Transmission for Ubicomp, CEET 2016

[27] M. Kaleem GALAMALI, Assoc. Prof Nawaz MOHAMUDALLY, Model of Maximum CBR Distance Travelled by packets in MANETs using Location-Aware Transmission for Ubicomp, CEET 2016

[28] M. Kaleem GALAMALI, Assoc. Prof Nawaz MOHAMUDALLY, Model of Minimum CBR Distance Travelled by packets in MANETs using Location-Aware Transmission for Ubicomp, CEET 2016

[29] M. Kaleem GALAMALI, Assoc. Prof Nawaz MOHAMUDALLY, Model of Range CBR Distance Experienced by Transmissions in MANETs using LocationAware Transmission for Ubicomp, CEET 2016

[30] M. Kaleem GALAMALI, Assoc. Prof Nawaz MOHAMUDALLY, Trend Analyses of Parameters of Equations for Sender Node Energy Savings Achievable in ubicomp MANETs using Location-Aware Transmission, ACCN 2017

[31] Markus Bylund and Zary Segall, Towards seamless mobility with personal servers, 2004.

[32] Masugi Inoue, Mikio Hasegawa, Nobuo Ryoki and Hiroyuki Morikawa, Context-Based Seamless Network and Application Control, 2004

[33] Xiang Song, Umakishore Ramachandran, MobiGo: A Middleware for Seamless Mobility, College of Computing Georgia Institute of Technology, Atlanta, GA, USA, August 2007

[34] Budzisz, Ferrús, R., Brunstrom A., Grinnemo, K, Fracchia, R., Galante, G., and Casadevall, F. Towards transport-layer mobility: Evolution of SCTP multihoming, March 2008

[35] Paul Dourish \& Genevieve Bell, Divining a digital future, 2011.

[36] Xiang Song, Seamless Mobility In Ubiquitous Computing Environments, PhD Thesis, Georgia Institute of Technology, August 2008

[37] Kevin O Mahony, Jian Liang, Kieran Delaney, User-Centric Personalization and Autonomous Reconfiguration Across Ubiquitous Computing Environments, NIMBUS Centre Cork Institute of Technology, Cork, Ireland, UBICOMM 2012

[38] Pablo Vidales, Seamless mobility in 4G systems, Technical Report, University of Cambridge, Computer Laboratory, Number 656, November 2005 
[39] João Pedro Sousa and David Garlan, Aura: An Architectural Framework for User Mobility in Ubiquitous Computing Environments, School of Computer Science, Carnegie Mellon University, USA, August 2002

[40] Dennis Lupiana, Ciaran O'Driscoll, Fredrick Mtenzi, Defining Smart Space in the Context of Ubiquitous Computing, Dublin Institute of Technology, Ireland, Special Issue on ICIT 2009 Conference - Web and Agent Systems, 2009

[41] N.S.V.Shet1, Prof.K.Chandrasekaran2 and Prof. K.C.Shet3, WAP Based Seamless Roaming In Urban Environment with Wise Handoff Technique, International Journal of UbiComp (IJU), Vol.1, No.4, October 2010

[42] Yipeng $\mathrm{Yu}$ Dan He Weidong Hua Shijian Li Yu Qi Yueming Wang Gang Pan, FlyingBuddy2: A Braincontrolled Assistant for the Handicapped, Zhejiang University, UbiComp'12, September 5-8, 2012.

[43] Jing Su, James Scott, Pan Hui, Jon Crowcroft, Eyal de Lara Christophe Diot, Ashvin Goel, Meng How Lim, and Eben Upton, Haggle: Seamless Networking for Mobile Applications, 2007

[44] Rui Han, Moustafa M. Ghanem, Li Guo, Yike Guo*, Michelle Osmond, Enabling cost-aware and adaptive elasticity of multi-tier cloud applications, Future Generation Computer Systems, 2012

[45] Byrav Ramamurthy, K. K. Ramakrishnan, Rakesh K. Sinha, Cost and Reliability Considerations in Designing the NextGeneration IP over WDM Backbone Networks, 2012.

[46] Bhavish Aggarwal, Aditya Akella, Ashok Anand, Athula Balachandran, Pushkar Chitnis, Chitra Muthukrishnan, Ram Ramjee and George Varghese, EndRE: An End-System Redundancy Elimination Service for Enterprises, NSDI 2010, San Jose, CA

[47] Ashok Anand, Vyas Sekar and Aditya Akella, SmartRE: An Architecture for Coordinated Network-wide Redundancy Elimination, SIGCOMM 2009, Barcelona, Spain

[48] John Breeden II, "Smart-phone battery life could double without better batteries", Nov 14, 2012

[49] Andy Boxall, "When will your phone battery last as long as your kindle", December 5, 2012.

[50] Imielinski, T. and Navas, J.C. (1999). GPS-based geographic addressing, routing, and resource discovery. Comms. ACM, Vol. 42, No. 4, pp. 86-92.

[51] Hightower, J. and Borriello, G. (2001). Location Systems for Ubiquitous Computing. IEEE Computer, Vol. 34, No. 8, August, pp. 57-66.

[52] Harter, A., Hopper, A., Steggles, P., Ward, A. and Webster, P. (2002). The Anatomy of a Context-Aware Application. Wireless Networks, Vol. 8, No. 2-3, Mar-May, pp. 187-197.

[53] Hightower, J., Brumitt, B. and Borriello, G. (2002). The Location Stack: A Layered Model for Location in Ubiquitous Computing. Proceedings of the 4th IEEE Workshop on Mobile Computing Systems \& Applications (WMCSA 2002), Callicoon, NY, USA, June, pp. 22-28.

[54] Graumann, D., Lara, W., Hightower, J. and Borriello, G. (2003). Real-world implementation of the Location Stack: The Universal Location Framework. Proceedings of the 5th IEEE Workshop on Mobile Computing Systems \& Applications (WMCSA 2003), Monterey, CA, USA, October, pp. 122-128.

[55] Ko, Y., \& Vaidya, N. H. (2000). Location-aided routing (LAR) in mobile ad hoc networks. Wireless Networks, 6(4), 307-321.

[56] Liao, W.-H., Tseng, Y.-C., \& Sheu, J.-P. (2001). GRID: a fully location-aware routing protocol for mobile ad hoc networks. Telecommunication Systems, 18(1), 37-60.

[57] Kuhn, F., Wattenhofer, R., Zhang, Y., \& Zollinger, A (2003). Geometric ad-hoc routing: of theory and practice. In Proceedings of the ACM (PODC'03) (pp. 63-72).

[58] Jiang, X., \& Camp, T. (2002). Review of geocasting protocols for a mobile ad hoc network. In Proceedings of the Grace Hopper Celebration (GHC).

[59] Ko, Y. \& Vaidya, N. H. (1999). Geocasting in mobile ad hoc networks: location-based multicast algorithms. In Proceedings of the IEEE (WMCSA'99) (pp. 101).

[60] Mauve, M., Fuler, H., Widmer, J., \& Lang, T. (2003) Position-based multicast routing for mobile ad-hoc networks (Technical Report TR-03-004). Department of Computer Science, University of Mannheim.

[61] Xu, Y., Heidemann, J., \& Estrin, D. (2001). Geographyinformed energy conservation for adhoc routing. In Proceedings of the ACM/IEEE (MOBICOM'01) (pp. 70-84).

[62] Hu, Y.-C., Perrig, A., \& Johnson, D. (2003). Packet leashes: a defense against wormhole attacks in wireless ad hoc networks. In Proceedings of the INFOCOM' 03 (pp. 19761986).

[63] Patwari, N., Hero III, A. O., Perkins, M., Correal, N. S., \& O'Dea, R. J. (2003). Relative location estimation in wireless sensor networks. IEEE Transactions on Signal Processing, 51(8), 2137-2148.

[64] Baldauf, M., Dustdar, S., \& Rosenberg, F. (2007). A Survey on Context Aware Systems. International Journal of Ad Hoc and Ubiquitous Computing, Inderscience Publishers. forthcoming. Pre-print from: http://www.vitalab.tuwien.ac.at/ florian/papers/ijahuc2007.pdf

[65] Hong, D., Chiu, D.K.W., \& Shen, V.Y. (2005). Requirements elicitation for the design of context-aware applications in a ubiquitous environment. In Proceedings of ICEC'05 (pp. 590-596)

[66] Neeraj Tantubay, Dinesh Ratan Gautam and Mukesh Kumar Dhariwal, A Review of Power Conservation in Wireless Mobile Ad hoc Network (MANET)", International Journal of computer Science Issues, Vol 8, Issue 4, No 1, July 2011.

[67] Wenrui Zhao, Mostafa Ammar and Ellen Zegura, "A Message Ferrying Approach for Data Delivery in Sparse Mobile Ad Hoc Networks", MobiHoc'04, May 24-26, 2004, Roppongi, Japan.

About Author (s):

Associate Professor Nawaz Mohamudally works at University of Technology, Mauritius (UTM) and has undertaken supervision of $\mathrm{MPhil} / \mathrm{PhD}$ Students for many years.

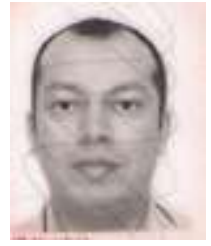

M. Kaleem Galamali is a part-time student (achieved M Phil Transfer on 28.10.2014, currently $\mathrm{PhD}$ student) at UTM under supervision of A.P. Nawaz Mohamudally. 